\title{
Import Growth and the Impact on the Florida Strawberry Industry ${ }^{1}$
}

\author{
Zhengfei Guan, Dong Hee Suh, Hayk Khachatryan, and Feng Wu ${ }^{2}$
}

\section{Introduction}

The United States is the second largest producer of strawberries after China. California and Florida account for about $98 \%$ of the US total production. According to the United States Department of Agriculture, National Agricultural Statistical Service (USDA-NASS 2016), California produced nearly 2.8 billion pounds of strawberries from 41,000 acres in 2015, while Florida produced approximately 240 million pounds from 11,000 acres. Florida mainly produces fresh strawberries in the winter season, while California produces both fresh and frozen strawberries year round. The winter production in Southern California is roughly at the same level with that of Florida (Suh, Guan, and Khachatryan 2016).

\section{Import Competition}

Mexico is a major import supplier of strawberries in the US market. Imported fresh strawberries from Mexico account for about $95 \%$ of total imported fresh strawberries in the US market; the rest are mainly from Canada. In recent years, the US strawberry industry has become increasingly concerned with competition from Mexico (Wu, Guan, and Suh 2017). According to the United States Department of Agriculture, Foreign Agricultural Service (USDA-FAS 2017), the volume of imported fresh strawberries from Mexico increased fourfold over a ten-year period, from

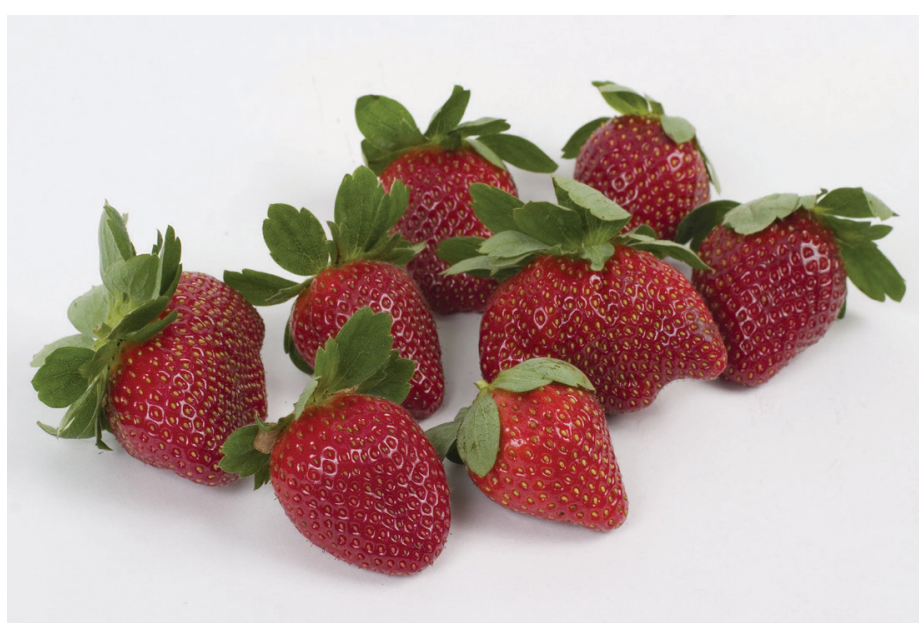

Credit:. Tyler Jones, UF/IFAS

93 million pounds in 2004 to 355 million pounds in 2014 (Figure 1). Mexico, a direct competitor of Florida, produces most of its strawberries in the winter season. In 2013, about 300 million pounds of strawberries were imported from Mexico compared to 233 million pounds of strawberries grown in Florida production. Over the years, Southern California has extended its strawberry production from early spring to late fall, which creates additional pressure on the Florida market. USDA-NASS statistics show Florida production value fell from $\$ 362$ million in 2010 to $\$ 245$ million in 2012, before recovering slightly to $\$ 291$ million

1. This is EDIS document FE1022, a publication of the Food and Resource Economics Department, UF/IFAS Extension. Published December 2017. Visit the EDIS website at http://edis.ifas.ufl.edu.

2. Zhengfei Guan, assistant professor, Food and Resource Economics Department, UF/IFAS Gulf Coast Research and Education Center, Wimauma, FL; Dong Hee Suh, assistant professor, Korea University, Seoul, South Korea; Hayk Khachatryan, assistant professor, Food and Resource Economics Department, UF/IFAS Mid-Florida Research and Education Center, Apopka, FL; and Feng Wu, research assistant scientist, Food and Resource Economics Department, UF/IFAS Gulf Coast Research and Education Center, Wimauma, FL.

The Institute of Food and Agricultural Sciences (IFAS) is an Equal Opportunity Institution authorized to provide research, educational information and other services

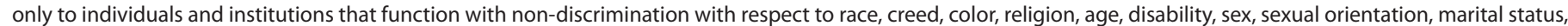

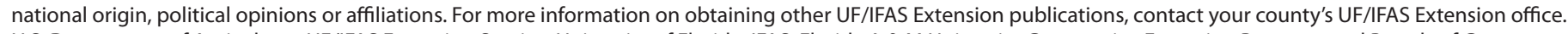
U.S. Department of Agriculture, UF/IFAS Extension Service, University of Florida, IFAS, Florida A \& M University Cooperative Extension Program, and Boards of County Commissioners Cooperating. Nick T. Place, dean for UF/IFAS Extension. 
in 2015. Market share for Florida has decreased over the years; the average market share over 2010-2014 was 39\% during the winter season (December through March).

Mexican strawberry acreage increased $60 \%$ over a five-year period, from about 17,000 in 2011 to 27,000 in 2016 (SIAPMexico 2017) (Figure 2). As a result, strawberry exports to the United States reached a record high of 364 million pounds in 2016 (United States Census Bureau 2017).

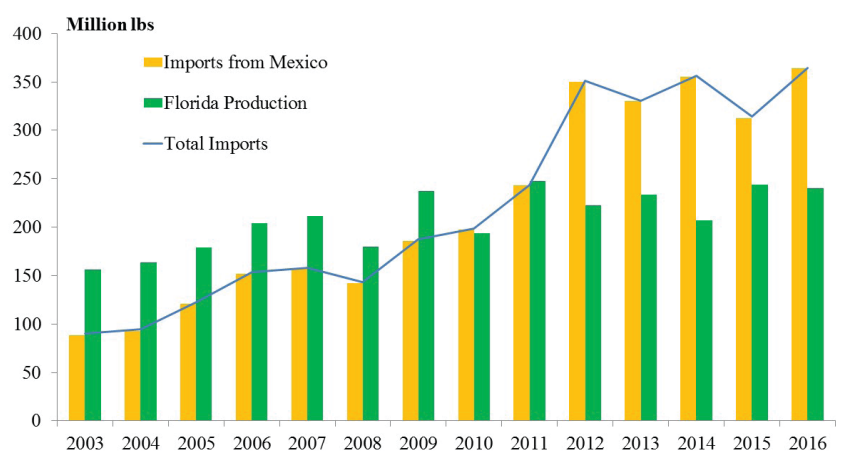

Figure 1. Florida production and imports from Mexico (Source: USDAFAS 2017)

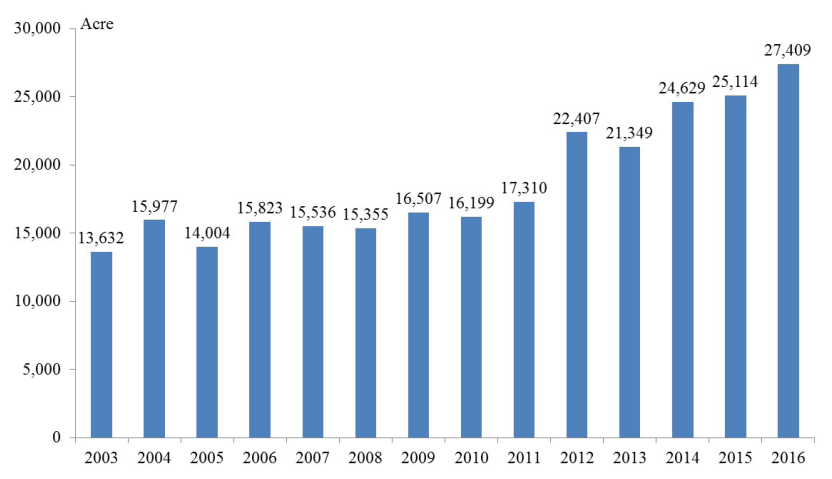

Figure 2. Mexican strawberry acreage (Source: SSIAP-Mexico 2017)

With the expansion of acreage, Mexican production increased significantly (Figure 3). In 2011, it was 505 million pounds; the amount doubled in 2016, reaching 1,032 million pounds. In the past, about one-third of Mexican production was for the fresh export market (Wu et al. 2017). In 2016, 35\% of the total production was sold to the US fresh market.

The expansion of the Mexican strawberry industry has been greatly facilitated by technology adoption and policy support. One of the critical technologies is the use of high tunnels. High tunnels extend the production season and increase crop yield. Mexico's Ministry of Agriculture promotes protected agriculture and provides subsidies to support investments in production facilities, such as greenhouses and high tunnels, under its "Strategic Project for Protected Agriculture" (Victoria, van der Valk, and Elings 2011). The trend in Mexican strawberry yield has increased with the adoption of high tunnels. Between 2001 and 2014, the average yield in Mexico increased from 30,000 pounds per acre to 41,000 pounds per acre. In contrast, the average yield in Florida was 25,000 pounds per acre during the same period.

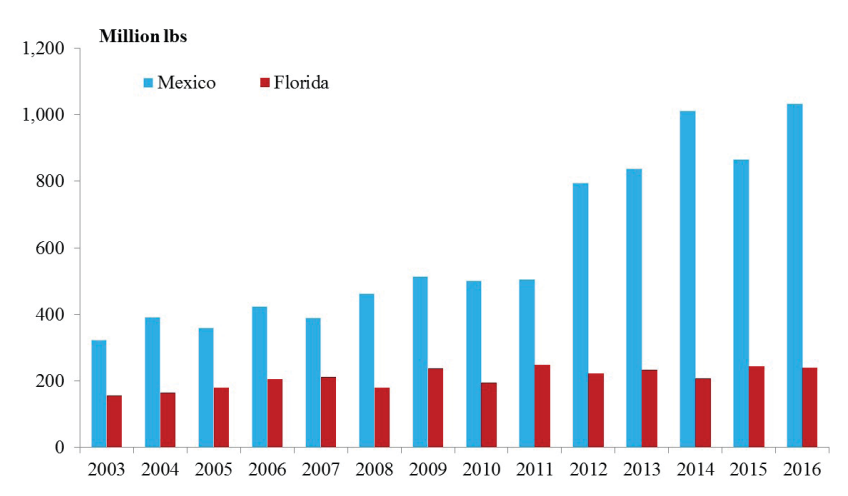

Figure 3. Strawberry production in Mexico and Florida, 2003-2016 [Note: Mexican produciton includes fresh and frozen fruit.] (Source: US Census Bureau 2016)

In 2013, the Mexican government stated that their industry goal was to double its strawberry production capacity (FreshFruitPortal.com 2013; Guan et al. 2015). If the goal is achieved, Mexico will have 43,000 acres of strawberries in production, which will further solidify its dominant market position in the winter season. The increasing competition from Mexico has prompted an important question: What are the effects of imports from Mexico on the Florida strawberry industry? An analysis by Suh, Guan, and Khachatryan (2017) using winter strawberry data over the 2010-2014 period showed that a 1-million-pound increase in Mexican weekly shipments on average would cause the Florida price to drop by 47 cents per flat. To put that in perspective, Florida average weekly shipment over the entire season is about 12 million pounds (weekly shipments vary over the season and peak in February). The authors further conducted a scenario analysis, showing that, if other things (such as acreage and marketing) are held constant, a $25 \%$ increase in imported strawberries could cause a reduction of $\$ 2,500$ per acre in the Florida strawberry farm revenue. Given the fact that the current profit margin is very low or even negative, losing these additional amounts would pose further challenges to the Florida industry. 


\section{Concluding Remarks}

To address the potential challenges, there are several areas in which the Florida strawberry industry could improve, including the adoption of new technologies and the development of new markets. The surging Mexican strawberry export market is driven by its competitive advantage in labor costs. Compared to Florida, the Mexican strawberry production labor cost is approximately $\$ 6,000$ less per acre; that is less than one-half of the labor cost in Florida (Wu, Guan, and Garcia-Nazariega 2017). Therefore, the development and adoption of labor-saving technologies is critical and will have a fundamental impact on the market position of the Florida industry. The development of new markets is also important to increase market demand and decrease pressures from oversupply in the existing market. Florida growers could also explore changes in production and management practices (e.g., double-cropping) to diversify and increase farm revenue.

\section{References}

FreshFruitPortal.com. 2013. Mexico Invests in Doubling Strawberry Plantations. http://www. freshfruitportal.com/news/2013/08/21/mexico-investsin-doubling-strawberry-plantations/?country=unitedstat es

Guan, Z., F. Wu, F. Roka, and A. Whidden. 2015. "Agricultural Labor and Immigration Reform." Choices 30(4). http:// www.choicesmagazine.org/UserFiles/file/cmsarticle_476. pdf

Servicio de Información Agroalimentaria y Pesquera (SIAP) of Mexico. 2017. Statistical Yearbook of Agricultural Production. http://www.gob.mx/siap/

Suh, D.H., Z. Guan, and H. Khachatryan. 2017. "The Impact of Mexican Competition on the U.S. Strawberry Industry." International Food and Agribusiness Management Review. Forthcoming. https://doi.org/10.22434/ IFAMR2016.0075

United States Department of Agriculture, National Agricultural Statistics Service (USDA-NASS). 2016. Quick Stats. Washington, DC: USDA-NASS.

United States Census Bureau. 2017. World Trade Atlas. Washington, DC: U.S. Census Bureau.

United States Department of Agriculture, Foreign Agricultural Service (USDA-FAS). 2017. Global Agricultural Trade System. Washington, DC: USDA-FAS.
Victoria, N., O. van der Valk, and A. Elings. 2011. Mexican Protected Horticulture: Production and Market of Mexican Protected Horticulture Described and Analysed. Report GTB-1126. Wageningen UR (Wageningen, Netherlands) and Dutch Agricultural Economic Research Institute (The Hague).

Wu, F., Z. Guan, and M. Garcia-Nazariega. 2017. Comparison of Labor Costs between Florida and Mexican Strawberry Industries. FE1023. Gainesville: University of Florida Institute of Food and Agricultural Sciences. http://edis.ifas. ufl.edu/fe1023

Wu, F., Z. Guan, J.J. Arana-Coronado, and M. GarciaNazariega. 2017. An Overview of Strawberry Production in Mexico. FE1014. Gainesville: University of Florida Institute of Food and Agricultural Sciences. http://edis.ifas.ufl.edu/ fe1014

Wu, F., Z. Guan, and D.H. Suh. 2017. “The Effects of Tomato Suspension Agreements on Market Price Dynamics and Farm Revenue." https://doi.org/10.1093/aepp/ppx029 